\title{
Expresiones críticas representadas en los discursos de películas de finales de los 60's: 2007: Una Odisea del Espacio, El Planeta de los Simios y Solaris*
}

Critical expressions represented in the film discourses of the late sixties: 2007: A Space Odyssey, Planet of the Apes and Solaris

Expressões críticas representadas nos discursos dos filmes do final dos anos 1960: 2001: Uma Odisseia no Espaço, O Planeta dos Macacos e Solaris.

DOI: https://doi.org/10.21803/pensam.v12i22.257

Laura Salcedo Díaz

https://orcid.org/0000-0003-2495-2930

\section{¿Cómo citar este artículo?}

Salcedo. L. (2019). Expresiones críticas representadas en los discursos de películas de finales de los 60's: 2001: Una Odisea del Espacio, El Planeta de los Simios y Solaris. Pensamiento Americano, 12(23) 200-224. DOI: https://doi.org/10.21803/pensam.v12i22.257

\section{Resumen}

El presente trabajo se ocupa de analizar tres obras cinematográficas de finales de la década de los sesenta sobre los viajes espaciales: 2007: Una Odisea del Espacio, El Planeta de los Simios y Solaris. Se analizan diálogos, argumento principal y situaciones representadas en las imágenes de cada una de estas producciones y se identifican discursos de la época, que dan cuenta de un conjunto de tensiones, temores y expectativas. Así, los personajes, el paisaje y las situaciones terminan siendo recursos de expresión de las inquietudes generadas por los avances tecnológicos, del rechazo a ciertas tradiciones, de las preocupaciones por la relación hombrenaturaleza, y otros temas que se encontraban en el imaginario de los realizadores, pero que también dan cuenta del contexto en que se realizaron las obras cinematográficas. Precisamente por eso éstas constituyen, como vestigios de la actividad humana, recursos de análisis del pasado.

Palabras Clave: Transformaciones, discurso, contracultura, 1968, representaciones, cine, imágenes, películas.

\begin{abstract}
In the present work three cinematographic works of the end of the sixties on space travel are analyzed: 2001: A Space Odyssey, The Planet of the Apes and Solaris. Dialogues, main argument and situations represented in the images of each of these productions are analyzed, and discourses of the time are identified, which account for a set of tensions, fears and expectations. Thus, the characters, the landscape and situations, end up being resources for expressing the concerns generated by technological advances, the rejection of certain traditions, concerns about the relationship between man and nature, and other topics that were in the imaginary of the filmmakers, but that also give an account of the context in which the cinematographic works were made. Precisely for this reason they constitute, as vestiges of human activity, resources for the analysis of the past.
\end{abstract}

Key words: Transformations, discourse, counterculture, 1968, representations, cinema, images, films.

* El texto es un artículo científico que surge del proyecto de investigación desarrollado en el marco del Doctorado en Ciencias Sociales con el apoyo y patrocinio de la Universidad del Norte, Colciencias y el Instituto de Altos Estudios Sociales y Culturales de América Latina y el Caribe. 


\section{Resumo}

O presente trabalho trata da análise de três obras cinematográficas do final dos anos 60 sobre as viagens espaciais, 2001: Uma Odisseia no Espaço, Planeta dos Macacos e Solaris. Analisando cada uma dessas produções cinematográficas em vários de seus diferentes elementos constituintes, como diálogos, enredo principal e situações representadas nas imagens, é possível identificar características de um tempo de tensões e medos, mas também de expectativas elevadas. Assim, os personagens e situações acabam sendo recursos de expressão das preocupações geradas pelos avanços tecnológicos, a rejeição de certas tradições, as preocupações sobre a relação homem-natureza e outras questões que, sem dúvida, estavam na mente dos cineastas, mas que também moldaram esse momento na história em que os filmes foram feitos. É precisamente por isso que eles constituem, como vestígios da atividade humana, recursos de análise do passado.

Palavras-chave: Transformações, discurso, contracultura, 1968, representações, cinema, história.

\section{Perfil}

\section{Laura Salcedo Díaz}

Politologa con Enfasis en Gobierno y Politicas Publicas (Universidad del Norte, Barranquilla, Colombia).
Magister en Administración de Proyectos (Universidad para la Cooperación Internacional, San José de Costa Rica). Estudiante del Doctorado en Ciencias Sociales (Universidad del Norte, Barranquilla). Becaria de Uninorte y Colciencias (Convocatoria 757 de 2016). Investigadora del Grupo Memorias del Caribe, integrante del Instituto de Altos Estudios Sociales y Culturales de América Latina y el Caribe. aurasalcedo@uninorte.edu.co . 


\section{Introducción}

Las producciones cinematográficas hacen posible, tal y como lo afirmaba para el caso de las pinturas un reconocido historiador especialista en el Renacimiento, leer "las estructuras de pensamiento y representación de una determinada época" (Burckhardt, 2004, p. 11). Esta idea constituye el punto de partida de un ejercicio de análisis historiográfico aquí presentado, cuyo propósito no es otro que el de indagar cómo se representan algunos de los rasgos de un momento específico de la historia en una pequeña muestra de imágenes y discursos integrados en algunos filmes. Se analizan entonces tres películas de 1968, año que es considerado como representativo del siglo $X X$, un momento en el que convergen diversas corrientes de pensamiento y acción que dan lugar a fenómenos, algunos largamente cultivados y de proyección, otros fugaces, pero que en su conjunto hicieron parte de un momento de la historia del siglo pasado que al día de hoy sigue considerándose como un instante de rupturas, de importantes transformaciones, y también, es preciso mencionarlo, de continuidades. Toda esa dinámica se evidencia a través de múltiples expresiones de la sociedad, entre ellas las artísticas, que constituyen una de las formas de materialización de lo que se puede considerar el "espíritu de la época", concepto acuñado por autores como Hegel (2017) y Burckhardt (1869) que denota la existencia de algunas tendencias, que aunque en el año analizado no se desarrollan de forma compacta si comparten rasgos, especialmente en el norte de América y en el continente Europeo.

Las películas objeto de estudio, 2001: Una Odisea del Espacio, El Planeta de los Simios y Solaris, presentan unos discursos y puestas en escena que hacen las veces de vestigios del pasado, en principio porque en ellas se perciben inquietudes de la sociedad del momen- to. Las tres además de tener como argumento común y central, los avances tecnológicos y los viajes al espacio, integran percepciones y representaciones propias de finales de los sesenta, época en la que se comienzan a propagar temores por el futuro de la humanidad, lo cual depende de lo que las sociedades y gobiernos de estas decidan hacer con los recursos y capacidades de las que disponen. Inquietudes relacionadas especialmente por los avances tecnológicos, que generan desconfianza por los posibles cambios negativos derivados de la relación hombre-naturaleza. Las tendencias, formas sociales y valores de crítica y desafección social están presentes en ese momento en que emergen numerosas perspectivas, por ejemplo, la contracultura y el rechazo a "ciertas tradiciones" por parte de grupos progresistas, como juventudes de países occidentales universitarios, mujeres escolarizadas, movimientos afroamericanos, entre otros. Es un instante de resignificación entre lo que los individuos pueden decidir con respecto a su vida privada y su cuerpo, y entre lo que los Estados pueden causar por acción u omisión, por ejemplo, en la Guerra de Vietnam o en la Guerra Fría, al determinarse por parte de las potencias el uso de armas de destrucción masiva o la continuación de la participación en una guerra ajena, respectivamente.

A partir de lo anterior, el desarrollo del texto se organiza considerando el objetivo central de realizar un análisis de la relación que se pueda percibir entre la imagen y el discurso de las películas objeto de estudio con el contexto de la época: en primer lugar, se hace una descripción general de lo que significa para el análisis historiográfico el estudio del cine en sus imágenes y discursos; en segundo lugar, se hace mención de los procesos más representativos de la época y las características generales de lo que expresan las tres películas; y en tercer lugar, se expone el análisis de los 
mencionados elementos visuales y verbales de las producciones cinematográficas.

\section{El análisis de las imágenes y el discurso}

El ejercicio de analizar las imágenes ha obtenido denominaciones como la otorgada por Huizinga (2001) de "método del mosaico". El autor afirma que si se estudia la manera como se forman las imágenes al detalle, se podrá reconstruir y notar la semejanza entre los elementos estéticos, como la creación artística, y la historia. El cine, entendido como un elemento estético y conformado por una serie de imágenes en movimiento, sirve como un recurso para el análisis de la historia (Burke, 2005). En este trabajo, por ejemplo, el interés inicial consistió en un estudio exploratorio de filmes alrededor del año 1968 que trataran temas relacionados con aspectos tecnológicos y viajes al espacio, para observar de qué manera se representan elementos del añoy década en que se producen y estrenan estos. Vale destacar que solo en ese año salieron a la luz más de ciento setenta y siete películas, entre las cuales sobresalen tres relacionadas entre sí, las ya mencionadas, 2001: Una Odisea del Espacio, El Planeta de los Simios, y Solaris, las dos primeras norteamericanas, y la última rusa.

Sobre estas películas se han realizado distintos estudios de sus imágenes. Es el caso de 2007: Una Odisea del Espacio, que ha tenido numerosas interpretaciones. Al respecto se han destacado alegorías a la relación hombre-simio desde los enfoques de Nietzsche (como el trabajo de Gaviria (2012), y el de Zepke (2007)) y Zaratustra (Gisbert, 2012). Donald MacGregor (2009) vincula las actitudes de los protagonistas y los hechos del filme a las actitudes apolínea y dionisíaca. Por otro lado, se ha visto cómo el largometraje representa tanto la concepción, como el nacimiento y la muerte, no solo por las imágenes de un bebé y un anciano, sino por el trayecto de la nave como paralelismo a la concepción (Wheat, 2000). Otra interpretación es la de Jerome Agel (1970), quien afirma que la nave que se observa en la película representa un cuerpo y una célula espermática, y Bowman (protagonista de la película) es la vida, mientras Júpiter (el planeta al que viajan) es el óvulo.

Cada autor utiliza enfoques únicos, en este caso se hace un análisis conforme a las secuencias y argumentos propios de las películas. Se centra la atención en la fotografía en movimiento, leída como un documento, para identificar las representaciones, críticas y demás apreciaciones que sean pertinentes al estudio; como lo que hace un fotógrafo, el cual por sus escogencias "está trabajando sobre la base de una actitud sesgada análoga a la que podemos apreciar los historiadores" (de Meneses, 2002, p. 12). Para este documento se deja de lado la disertación sobre los atributos de las imágenes, la denominada iconografía, y se alude a un estudio del cine como una pista, una fuente documental (Díaz, s.f), lo que Renier (2016) Ilama un vestigio del pasado en el presente (Edwards, 2012).

El cine relacionado con la historia se ha planteado de distintas maneras, una pedagógica, una como representación, y otra como medio de expresión crítica en un momento determinado. Por ejemplo, como herramienta didáctica para la pedagogía, Caparrós (1997) plantea unos recursos para la enseñanza de la historia por medio de películas que reflejan distintas etapas a lo largo de la humanidad en su libro titulado "100 películas sobre Historia Contemporánea". Como medio de expresión crítica un ejemplo es la manipulación del cine observada por Manuel Trenzado Romero (1999) en "Cultura de masas y cambio político: El cine español de la transición", en el que muestra cómo la política incide en el cine. Pero el estudio de Trenzado (1999) también es un estudio de análisis de representación, ya 
que da a conocer cómo el cine es un elemento clave para la generación de imaginarios y la expresión de críticas en un momento de transición política en España de un gobierno y Estado dictatorial a uno democrático.

A lo anterior se le puede sumar que el cine, no solo es un recurso didáctico, de crítica, representación y expresión, sino que también es un generador de creencias en hechos que no ocurrieron. Ferro (2008) encuentra fundamentos para afirmar que la cinematografía es muy significativa para la construcción de imaginarios sobre ciertos acontecimientos, ya que incluso aspectos que divergen de los hechos históricos han quedado impregnados en la conciencia humana, lo que manifiesta el gran poder del cine como multiplicador de realidades y percepciones extendidas como reales. Como resultado de esta ineludible manipulación existente, sobresale lo imperioso de recurrir, además de al método del mosaico (que analiza la relación imagen-historia), al análisis de representaciones y al método crítico de análisis cinematográfico, al menos parcialmente.

El método crítico de análisis cinematográfico que menciona Ferro (1995) consiste, primero, en ocuparse del cine como documento histórico; segundo, en comprobar el papel de los filmes como guías de publicidad y propaganda política, para verificar la fuerza del medio visual; el estudio de la repercusión del cine en la sociedad y el análisis del lenguaje evidente en la cinematografía, son el tercer y cuarto paso; y el quinto, que es la propuesta del autor, consiste en enlistar las películas de acuerdo a los modos como dialogan o se posicionan frente a la realidad. Ejemplo de la aplicación de este método son el trabajo de Paz y Montero en su libro (1995) "Historia y cine: realidad, ficción y propaganda" y el de Montero y Paz (1997) "La historia que el cine nos cuenta: el mundo de la posguerra 1945-1995".
Hasta este punto es posible identificar elementos particulares sobre qué y cómo estudiar la relación entre cine e historia, en este caso las imágenes como representación, con los métodos del mosaico y el crítico cinematográfico. Vale agregar a esto que las películas unifican imágenes, las cuales pueden ser consideradas fuentes documentales de información, pero además contienen y dan forma a una serie de discursos que en la mayoría de las ocasiones reflejan las perspectivas de los directores, su inspiración, ligada por supuesto a las observaciones que estos hacen de lo que les rodea.

Vinculado a lo anterior, la premisa que se desarrolla en este texto es que el cine es una fuente de información y además es un vehículo de expresión. Cercanos a la alusión del cine como vehículo de comunicación de expresiones del momento a partir del discurso, y que también incluyen componentes del cine como fuente documental, son los trabajos de Zabala (2003) "Elementos del discurso cinematográfico" y Tal (2005), y su artículo "Alegorías de memoria y olvido en películas de iniciación: Machuca y Kamchatka". Otro ejemplo de análisis de discursos en las películas es el ya mencionado de Romero (1999), quién resalta que, durante la transición de dictadura a democracia en España, el discurso político influyó tanto en el discurso de las películas como en el proceso cinematográfico. Él percibe al cine como una institución social y a las películas como "discursos comunicativos concretos".

Por esto, se hace un análisis del discurso a partir del estudio de los fragmentos de diálogo de las películas analizadas. Para lograrlo se citarán líneas de texto y discusiones que sirven para fortalecer las ideas que refleja el autor (director o guionista del filme) desde su perspectiva como un ser inserto en la sociedad. Los fragmentos de imágenes de las películas también servirán como apoyo a la interpreta- 
ción de las ideas que reflejan los largometrajes objeto de estudio. Ideas que puede que sean de reflexión, contestatarias o críticas respecto a algún aspecto del contexto, que es lo que sucede cuando las películas, como discursos comunicativos concretos, expresan posiciones en contra o a favor del espíritu de la época. A continuación, se observa lo encontrado en las películas objeto de estudio, no sin antes establecer una lectura y descripción general del contexto y de las obras de arte cinematográficas en sí.

\section{8: Instante de rupturas y transformacio- nes}

Como se ha mencionado, 1968 es un año en el que convergen controversias políticas, científicas, sociales y religiosas, en especial en Norteamérica y Europa. Hace parte de una década que enmarca en el escenario político, luchas, por los derechos civiles y políticos o en protesta contra la Guerra de Vietnam, y magnicidios, como la muerte de Martin Luther King y de
Robert Kennedy. En lo político, la primavera de Praga constituyó un ícono de la época en lo que respecta a formas de resistencia frente al dominio soviético al interior de su propia zona de influencia (Lázaro y Salcedo (comp), 2017).

Desde el escenario social se discutía acerca de la necesidad de revisar conceptos considerados como tradicionales. Así nacieron o se fortalecieron corrientes ecologistas y en pro de la diversidad sexual. De hecho, Mayo del 68 fue el resultado del rechazo de jóvenes a las imposiciones en el modo de vivir de las generaciones precedentes (Laurent, 2009). Destacan distintas controversias y movilizaciones sociales masivas que hoy en día son recordadas con el nombre de "sesentayochismo", protagonizado principalmente por grupos de juventudes impregnadas de un nuevo espíritu, pero también por diferentes actores y movimientos sociales que a su manera respondieron al "llamado de una época" (Rábago, 2013).

Hubo otros tantos sucesos de gran trascen-

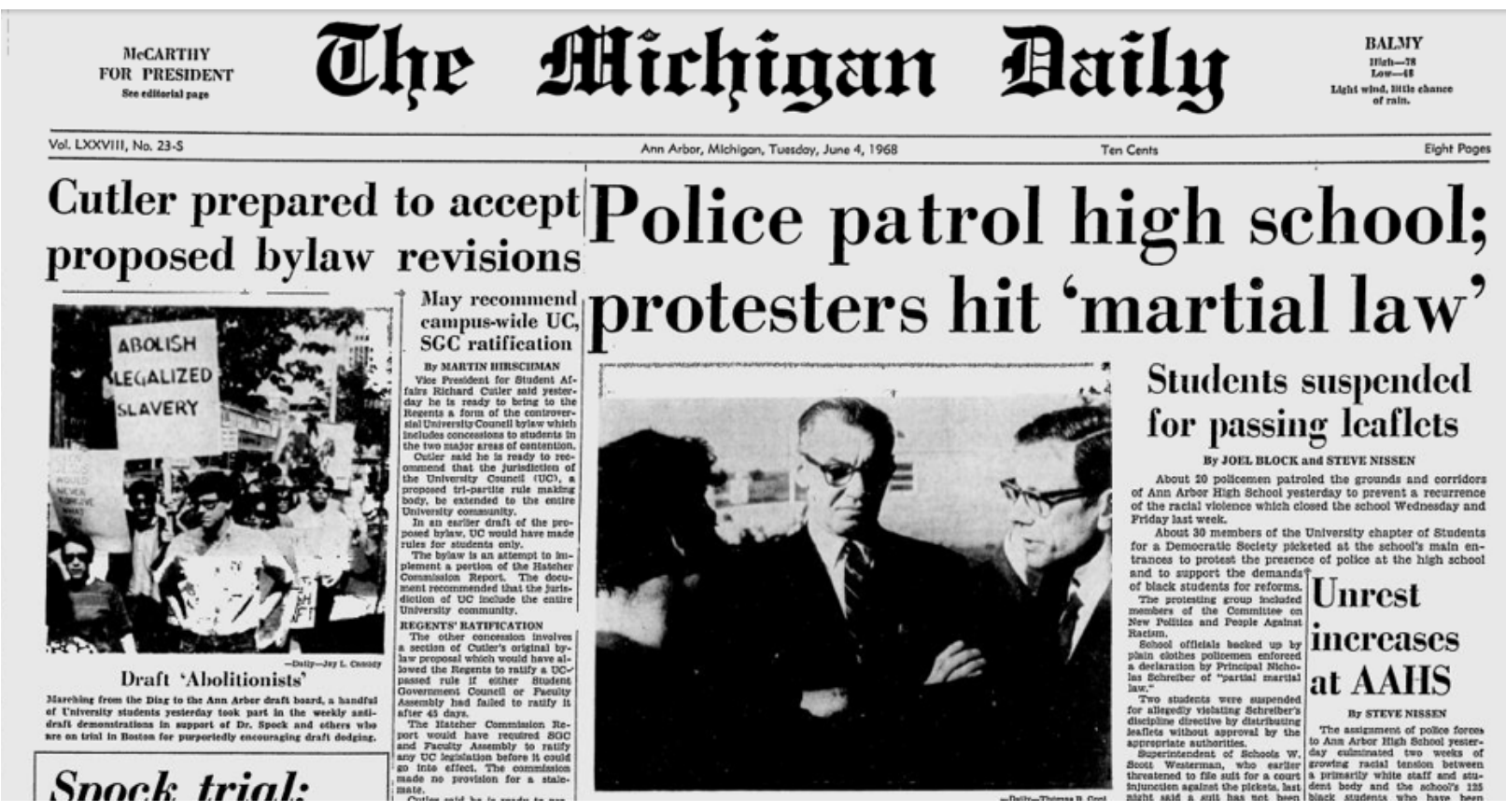

Figura 7. Primera página del diario The Michigan Daily con titulares sobre el racismo en E.U.

Fuente: The Michigan Daily, 4 de junio de 1968.

Pensamiento Americano Vol. 12 - No. 23 - 2019 • Enero - Junio • Corporación Universitaria Americana • Barranquilla, Colombia • ISSN: $2027-2448$. http://publicaciones.americana.edu.co/index.php/pensamientoamericano/index 
dencia política y cultural que se desarrollaron en 1968. Fueron asesinados más de 325 estudiantes en México por parte de un grupo paramilitar que disolvió una marcha del "Movimiento Estudiantil 1968" que luchaba por cambios en el gobierno de turno en este país. Se le suma a lo anterior, el mencionado asesinato de Martin Luther King en Estados Unidos, que siguió al de Malcolm X, ocurrido tres años antes. Por lo que las protestas en Estados Unidos y en otros países por los derechos civiles se radicalizó (Kurlansky \& Antón, 2005).

Diversos ámbitos de la cotidianidad fueron lugares de expresión de todos esos reclamos. Muestra de ello fue la forma como los cambios políticos y sociales que se reclamaban en los sesenta influyeron en el ámbito cultural, en la música, la forma de vestir de las personas, las libertades sexuales, y hasta en la literatura $y$ el cine. Es el momento en el que el rock de Gran Bretaña era escuchado en muchas partes (como The Beattles), la literatura vio florecer el Boom Latinoamericano, algunos movimientos de mujeres letradas luchaban por ser iguales y dueñas de sí mismas, y los afroamericanos buscaban igualdad de condiciones y reivindicación de derechos civiles.

En el ámbito religioso, se celebró el Concilio del Vaticano II, el cual duró dos años y buscó una reestructuración de la Iglesia Católica. Cambios en la estructura eclesiástica que para algunos de los miembros de este cuerpo religioso eran necesarios y con los cuales se podría seguir teniendo feligreses en los países católicos, o incluso incrementarlos, para evitar continuar viéndose afectados por las dudas que pudieran generarse dados los avances científicos de la época y otros procesos que cuestionaban la autoridad de la Iglesia. Entre los debates que se dieron en el momento, que confrontaban dogmas religiosos, estuvo el de la posibilidad del control de natalidad, que se manifestó en la comercialización de los anticonceptivos, de- sarrollo farmacéutico que cuestionaba la idea de religiones como la católica de que Dios es quien da y quita vida (Tirado, 2014).

Los sesenta fueron de tensa confrontación entre Estados Unidos y Rusia, guerra que por fortuna nunca estalló, por lo menos no a nivel de las grandes potencias, que sí se enfrentaron indirectamente en otros escenarios. Los dos protagonistas lucharon por la expansión de su respectiva zona de influencia política y por la neutralización de su enemigo en la labor de incorporar aliados. Figuraron sucesos que despertaron masiva atención, y en algunos casos críticas y movilizaciones a nivel internacional. Como la Crisis de los Misiles en Cuba, el levantamiento del muro de Berlín, la invasión de Bahía Cochinos y la intervención de ambos bloques en la Guerra de Vietnam. Los dos bloques también lucharon y fueron protagonistas en el terreno científico. Jugaron papeles antagónicos en la llamada Carrera Espacial, que derivó en logros como la llegada de, primero animales, y luego del ser humano a la luna en 1969 y la instalación de satélites para la transmisión masiva de televisión. Por supuesto, la propaganda a su favor, como ganadores, vencedores y aventajados en todos los terrenos, fue una estrategia política prioritaria. En ese contexto se producen películas resultado de la competencia por alcanzar el espacio y llegar a la luna, e incluso a otros planetas.

\section{Reseña de los filmes 2001: Una Odisea del Es- pacio, El Planeta de los Simios y Solaris}

El 27 de marzo del año 1968 se estrenó El Plantea de los Simios, una película estadounidense de ciencia ficción cuyo director fue Franklin Schaffner. Ésta trata del viaje al espacio de George Taylor, un coronel de Estados Unidos que buscaba salir de la tierra con expectativas de encontrar un lugar habitable. El filme inicia con un aterrizaje forzoso junto a la tripulación en un planeta no identificado, donde al 
llegar constatan que casi todos los pasajeros de la nave están vivos, excepto la única mujer que hacía parte del equipo, fallecida durante el viaje. Posteriormente, mientras recorren el planeta, se encuentran con un grupo de seres humanos quienes actúan de manera extraña. Además de que no pueden hablar, se comportan como animales, caminan como monos. Consecutivamente irrumpe un grupo de simios que pueden hablar, y muestran particular destreza en el uso de armas y que incluso son capaces de montar a caballo, efectuando de manera violenta una acción de captura sobre los humanos, que incluye a los astronautas recién llegados.

En esta línea de sucesos el único astronauta de la misión interplanetaria que sobrevive aparentemente es Taylor, quien lucha por no ser asesinado, y luego de la captura se esfuerza por evitar ser intervenido quirúrgicamente. Una operación del cerebro, que quieren realizarle los simios, los cuales son totalmente humanizados en su comportamiento y capacidades cognitivas, y quienes lo consideran un peligro y una anomalía por poder hablar, ya que se supone que los humanos son inferiores y no tienen esta capacidad. Una científica simio y su pareja tratan de ayudar al recién llegado humano. Lo que hace que sean perseguidos, no solamente por salvar la vida de Taylor, gran objetivo de las autoridades, sino también por postular teorías contrarías a las establecidas. Pensamientos rechazados por un sector de la población de simios que ejerce como autoridad político-religiosa y, al mismo tiempo, científica. Al final de la película Taylor logra escapar, y en una de las últimas escenas con gran sorpresa se topa con una parte de la estructura de la Estatua de la Libertad enterrada bajo la arena de una playa, a partir de lo cual concluye que no estaba en otro planeta, estaba en La Tierra que se encontraba ahora dominada por los simios.
El Paneta de los Simios es una de las obras destacadas del cine norteamericano y en el año 2001 pasó a integrar el Archivo Nacional de la Biblioteca del Congreso de los Estados Unidos al ser considerada como una película "cultural, histórica y estéticamente significativa". Similar reconocimiento recibió 2001: Una Odisea del Espacio.

El dos de abril de 1968 se estrenó 2001: Una Odisea del Espacio, considerada como de las más significativas obras del director Stanley Kubrick. El filme inicia con una escena ambientada cientos de miles de años atrás, en la que unos pre-homínidos encuentran un monolito que luego de tocarlo termina por transmitirles lo que se sugiere como unas capacidades superiores. La película incorpora posteriormente otra escena en la que, miles de años después de la primera, los humanos descubren un segundo monolito en la luna que envía señales. Un grupo de científicos norteamericanos son enviados a revisar este artefacto, y con ellos viaja HAL9000, una súper computadora que controla toda la nave, y que finamente termina asesinando a casi toda la tripulación por considerarlas un riesgo para el objetivo final de la misión. La película termina con el único sobreviviente encontrando al monolito.

En 1968 también estrenan Solaris, un filme ruso cuya trama está también enmarcada en la exploración del espacio. Trata del viaje de Jhon Kelvin a una estación espacial que queda frente al planeta Solaris. Al llegar a la estación se encuentra con dos científicos, y se entera de que el tercero, que era su amigo, se suicidó. Posterior a esto se da cuenta que el planeta tiene un océano, que es su objeto de estudio, que guarda un gran peligro para los cosmonautas ${ }^{1}$ puesto que de él emergen entidades capaces de adoptar aspectos físicos similares a los de los humanos. Los seres de Solaris son

1 La palabra Astronauta era la que utilizaba Estados Unidos para referirse a las personas que viajaban al espacio, mientras los rusos usaban el nombre de Cosmonautas para distinguir a sus viajeros al espacio.

Pensamiento Americano Vol. 12 - No. 23 • 2019 • Enero - Junio • Corporación Universitaria Americana • Barranquilla, Colombia • ISSN: 2027-2448 • $\mathrm{http} / / /$ publicaciones.americana.edu.co/index.php/pensamientoamericano/index 
capaces incluso de utilizar los traumas y sensaciones más íntimas de las personas, como sucede cuando uno de ellos utiliza la forma de la esposa de Kelvin, muerta hace más de diez años, para manipular el comportamiento de este. Como recurso para conjurar el peligro, los tres cosmonautas elaboran un plan que consiste en enviar una señal que elimine a los que ellos denominan "visitantes", es decir, los seres de Solaris. Sin embargo, Kelvin, enamorado y cegado por su intención de no perder a su supuesta esposa, decide impedir el plan e intentar dejar la estación para ir con ella a La Tierra. Finalmente, uno de los científicos convence a la esposa de Kelvin, que había desarrollado afecto por el cosmonauta, de la importancia de dejar que este siga con su vida sin tener que hallarse sujeto a una ilusión. La "visitante" desaparece y el protagonista decide quedarse en la estación a esperar por siempre a ver si ella regresa.

Las películas anteriores tienen varios aspectos en común. Además de los viajes al espacio, las tres abordan preguntas de interés sobre la razón como elemento que diferencia a los humanos de otras especies. Sin embargo, al observar a otros seres en los largometrajes, ya sean simios, visitantes, o una computadora, se encuentra que todos ellos poseen o logran desarrollar inteligencia, y además emociones y otras características similares a las humanas. Otro aspecto en común es que las tres películas se basan en escritos previos, El Planeta de los Simios y Solaris en novelas homónimas, cuyos autores son Pierre Boulle (1963) y Stanisław Lem (1961) respectivamente, mientras que 2001: Odisea del Espacio es una representación del cuento "El centinela" de Arthur C. Clarke² (1951). De igual manera, es posible afirmar que las tres han sido significativas para el público, no sólo por la acogida que tuvieron en su momento y en años posteriores, sino también por el hecho de que se elaboren secuelas $u$ otras versiones de cada película a lo largo de los años que han tenido también aceptación. Tal como lo mencionaba Ferro (2008) las películas quedan arraigadas en la mente de las personas.

Finalmente, es importante recordar que los tres largometrajes fueron estrenados en el año 1968, teniendo como un poderoso e influyente contexto los avances hasta ese entonces alcanzados en la carrera espacial, que inspiraban a los directores y al mismo tiempo generaban expectativas entre el público, lo que en buena medida podía augurar éxitos taquilleros para las películas. En este año el ser humano aún no llegaba a la luna y ya estos directores reproducían las expectativas de las personas de la época con respecto al desarrollo espacial. Otro elemento en común de los tres filmes es que tocan debates populares de la época, como las discusiones por los derechos de los animales, la existencia y origen del ser humano, entre otros, que tuvieron en estas películas espacios de representación. Con esto en consideración, se expone a continuación el análisis de dichas representaciones con base al estudio de las imágenes y el discurso de las tres.

\section{Imágenes y discurso de las películas te- niendo en cuenta su relación con el contex- to de la época}

Leer cierto contenido a partir de las imágenes es denominado "método del mosaico", que consiste en observar cómo distintas imágenes representan una época (Huizinga, 2001). Ese método es aplicado en este caso, y tras una lectura de lo que en ese complejo contexto de los sesenta sucedía, se procede a rescatar los mensajes más destacados de las películas que coinciden con perspectivas, posiciones o representaciones de la época. No implica esto que necesariamente los direc-

2 Posteriormente al estreno de la película Arthur Clarke publica una novela con el mismo nombre del film que se inspiró en su cuento El Centinela.

Pensamiento Americano Vol. 12 - No. 23 - 2019 • Enero - Junio • Corporación Universitaria Americana • Barranquilla, Colombia • ISSN: $2027-2448$. http://publicaciones.americana.edu.co/index.php/pensamientoamericano/index 
tores y libretistas estuviesen conscientes de que estaban representando un contexto, precisamente esa posición natural del productor de un arte es clave para resaltar que cada uno relata con el paradigma que lo cobija, expone un subconsciente que interpreta de acuerdo a las creaciones sociales que lo rodean o a las expectativas del futuro de acuerdo al presente que se vive.

Cada película reúne una serie de imágenes en movimiento a partir de las cuales es posible realizar apreciaciones sobre su relación con el contexto de la época. Para iniciar, se observan algunas de las imágenes más llamativas de las películas y la relación de las mismas con el contexto. Es menester mencionar que se considera al cine como una institución social y a las películas como "discursos comunicativos concretos" (Romero, 1999). Esta expresión de Romero es clave para este trabajo, realmente las películas como un todo son un discurso, pero también poseen unos diálogos que pueden ser objeto de análisis. Con esto en consideración se procede además a hacer una interpretación de dichos diálogos a la luz de lo sucedido en la época en que se estrenaron las películas objeto de estudio.

Figura 2. Primera escena de El Planeta de los Simios.

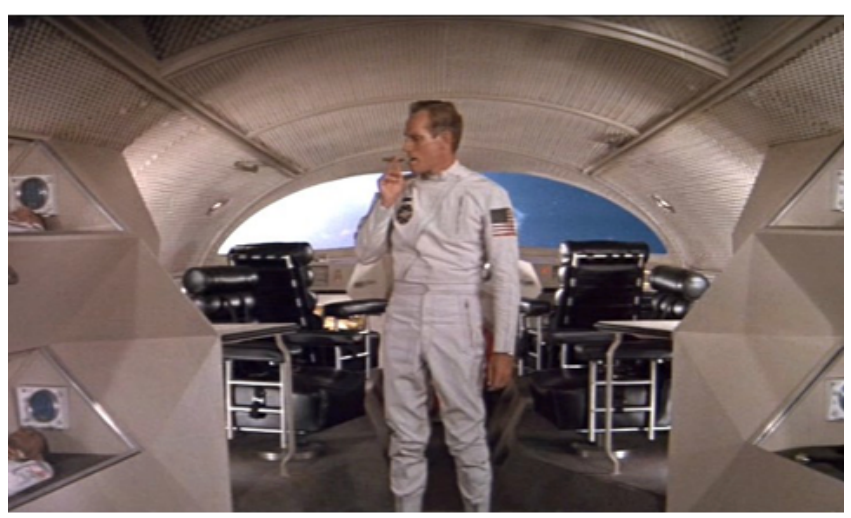

Fuente: El Planeta de los Simios (1968).

Las primeras escenas de El Planeta de los Simios corresponden a un monólogo de uno de los protagonistas, quien despierta en medio del viaje que hacen a un planeta desconocido en el año 1972. El hecho de que este sea el año de salida implica una perspectiva optimista de los viajes al espacio. En la figura 2 también se observa la bandera de Estados Unidos en los trajes delgados y cómodos. Estos aspectos demuestran una posición a favor de la carrera espacial con el liderato de Estados Unidos, con la percepción de que en 1972 ya se podría haber viajado con facilidad y comodidad a otros planetas y grandes distancias, logros que obtendría Estados Unidos a corto plazo, puesto que la película es de 1968 $y$ alude a que los sucesos se desarrollan solo cuatro años después.

El discurso de inicio de El Planeta de los Simios de Taylor, se presenta arraigado por debates existencialistas, religiosos y ecológicos, pero también científicos. Taylor despierta antes de que finalice su viaje y afirma que:

Según la teoría de Hasslein, un vehículo que viaja a la velocidad de la luz, la Tierra ha envejecido 700 años desde que nos fuimos, y nosotros casi nada. Así será. Al menos esto será cierto. Los que nos enviaron en esta misión han muerto hace mucho. Los que me leen ahora son de otra época. Espero que mejor. Dejo el siglo XX sin pesar, pero algo más. Eso es, si alguien me escucha. Nada científico. Solo personal. Desde aquí arriba, todo parece diferente. El tiempo limita. El espacio es eterno. Destruye el ego. Me siento solo. Eso es todo. Pero, dime: El hombre, esa maravilla del universo, esa paradoja gloriosa que me envió a las estrellas, ¿Aún hace la guerra a sus hermanos, y deja morir de hambre a los niños? (El Planeta de los Simios, 1968)

La década de los sesenta, cuando se produce la película, fue protagonizada por una ge- 
neración, con movimientos activistas, que indagaba y criticaba los estereotipos de sus antepasados, y temía sobre el futuro de la humanidad si se seguía con los avances en energía y bombas nucleares, y si se continuaba con los viajes al espacio y la falta de medidas políticas que favorecieran temas sociales y medio ambientales. En ese sentido, Taylor expresa este tipo de inconformidad con lo que han hecho los seres humanos cuando afirma "Pero mis sueños no son como los suyos. Pienso que en algún lugar del universo tiene que haber algo mejor que el hombre" (El Planeta de los Simios, 1968).

Por otro lado, en la misma figura 2, es posible observar al astronauta fumando un tabaco. A penas a mediados de la década de los sesenta se habían establecido unas pocas normas sobre fumar, y el hecho de que se prohibiera hacerlo en espacios cerrados es muy posterior. Lo que sí es típico de la época es el hecho de relacionar el fumar con una actividad de clase y de prestigio. Las empresas de cigarros, cigarrillos y tabacos utilizaban distintas estrategias publicitarias y las películas no se escaparon de esto.

Fumar era considerado algo normal en el ámbito privado de la vida social norteamericana, y la promulgación de la liberación de la sociedad con respecto a los esquemas mentales incide también en la tendencia a fumar, consumir drogas y alcohol. Sobre todo, teniendo en cuenta que durante la Segunda Guerra Mundial hubo un estancamiento de la industria del tabaco y un declive en ventas del producto. No es sino hasta los cincuenta y sesenta que se retorna la producción intensiva, teniéndose máximo auge al final de los sesenta cuando el consumo es masivo, esta tendencia en aumento llega hasta finales de la década, solo hasta inicios del setenta comienzan a promulgarse leyes e investigaciones que destacan el gran daño de fumar de forma activa y pasiva (Rubio y Rubio, 2006). Fumar tabacos incluso solía relacionarse con poder y estatus, moda que se consolidó hasta su máximo auge en los años 20 's. Incluso fue común relacionar el puro con imágenes del Che Guevara y Fidel Castro fumando habanos.

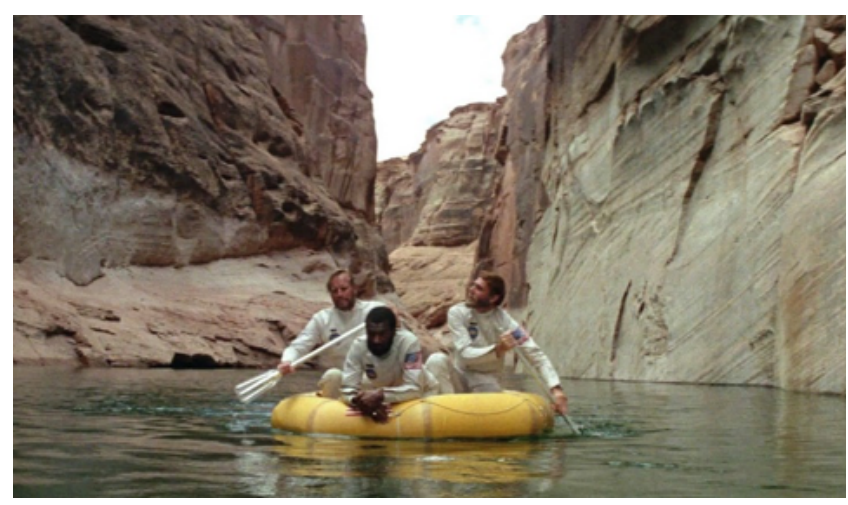

Figura 3. Escena de la llegada al planeta. Fuente: El Planeta de los Simios (1968).

La lucha de las comunidades afroamericanas en los sesenta por ser tratados por igual se refleja en el hecho de la inclusión de este astronauta como protagonista. En la anterior imagen (figura 3), se observa a los astronautas que acaban de llegar a un planeta desconocido después de un viaje de millones de años y aterrizan en un lago. De izquierda a derecha se encuentra al coronel George Taylor, a Dodge, que al parecer es un científico porque hace un estudio del suelo al llegar, cuyo resultado evidencia que el planeta no puede sostener vida, y Landon cuya profesión no se especifica. El hecho de que uno de los astronautas sea un coronel, es un vestigio de la importancia en la época de lo militar. En pleno escenario de la Guerra Fría se envía al espacio a un oficial y no solo a científicos civiles. También es posible percibir en la escogencia de los personajes una alusión a la lucha por la inclusión por "raza" de la época, teniendo en cuenta que Dodge, uno de los astronautas, y además con conocimientos científicos, es uno de los representantes escogidos en la 
tierra para este viaje espacial, sin diferenciarlo en ningún momento por su color de piel.

Posterior al aterrizaje, los tres astronautas se encuentran con un grupo de humanos que no pueden comunicarse con palabras y que actúan como animales y son cazados por un grupo de Simios que visten como humanos, caminan erguidos y tienen caballos. Uno de los astronautas (Dodge) muere huyendo por un disparo, y Taylor y Landon son capturados. A Landon le hacen una lobotomía para que no pueda hablar y Taylor, quien al principio no puede hablar por una herida sufrida en el cuello, es encerrado en una jaula. Cuando al fin puede hablar se le hace un juicio para decidir su destino (figura 4).

De esta forma, en la película se refleja constantemente la percepción crítica sobre lo que los hombres piensan sobre los animales como objetos destinados a ayudarlos en su bienestar. Es así como uno de los Simios que gobierna y lidera su grupo afirma sobre los humanos: "El hombre no es capaz de entender. Se le pueden enseñar algunos trucos. Eso es todo". Percepción inversa entre el trato del hombre a los animales. Se alude así mismo a la teoría de la evolución: "El simio evolucionó de una forma inferior de primate posiblemente el hombre" (El Planeta de los Simios, 1968).

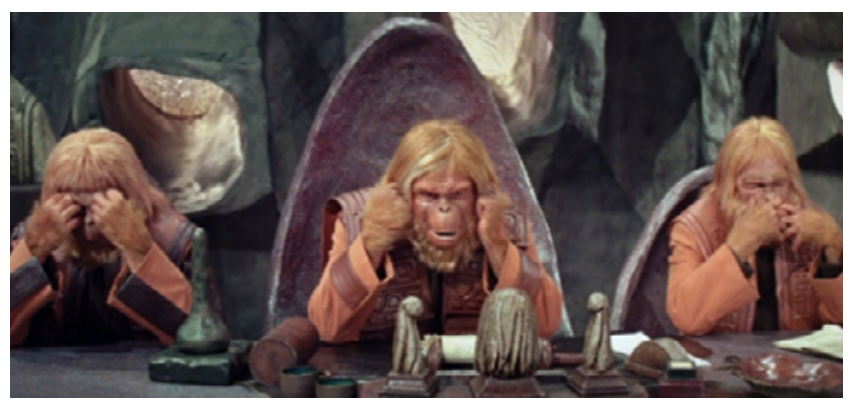

Figura 4. Escena del "Juicio a Taylor"

Fuente: El Planeta de los Simios (1968).

Observando ahora la imagen anterior (figura 4), se nota lo que decía Tal (2005) sobre alegorías de memoria y olvido, ya que las imá- genes y discursos de la película son similares a actitudes y aptitudes de la Iglesia Católica de épocas anteriores a la década de los sesenta. En esta imagen se observa una parte de la escena en la que se hace un juicio al humano encontrado, llama la atención que los jueces o el que parece ser el tribunal, incluso con funciones de gobierno según el comportamiento de quienes lo integran, está conformado por líderes religiosos, siendo esto último notorio por la vestimenta común que tienen, y su discurso a favor de la religión. Ejemplo de lo que menciona Huizinga (2001) de "método del mosaico", al notarse una relación evidente en la imagen con respecto a la realidad histórica, en este caso la vestimenta del clérigo representa una crítica al comportamiento y acciones que históricamente ha liderado la Iglesia Católica en contra de la ciencia y la evolución. Los jueces y sacerdotes determinan que el humano, al no ser un simio no puede ser juzgado, sino que únicamente debe ser sacrificado, clara muestra de las desigualdades ciudadanas del momento.

La alusión a la religión de los simios es una alegoría a la de la Iglesia Católica, el Simio que quiere que se sacrifique a Taylor afirma:

Jueces, mi caso es simple. Se basa en el primer artículo de fe. El todopoderoso creó al simio a su propia imagen. Le dió un alma y una mente. Le separó de las bestias de la jungla y le hizo amo del planeta. Esta verdad sacrosanta es evidente. El estudio correcto de los simios son los simios. Pero algunos jóvenes cínicos prefieren estudiar al hombre.

¡Sí! Científicos perversos que proponen la insidiosa teoría llamada evolución. (El Planeta de los Simios, 1968)

Sin embargo, la doctora Ziva dice que deben respetarle sus derechos el hombre. Llama mucho la atención porque solo hasta tiem- 
pos recientes se habla de derechos de los animales, aunque la lucha por la naturaleza por parte de los ecologistas es propia de la época. Esto es reflejo de los debates sobre si los animales son sujetos de derechos, cuando distintas creencias consideran que solo tienen derechos los seres humanos. Se percibe claramente el concepto de dominio teológico de acuerdo al Antiguo Testamento, libro de Génesis (1:20-28), donde el dominio sobre el mundo no humano es otorgado a Adán, incluso son ideas que defendió y practicó el ser humano y que están presentes en el mundo de las ideas de la llustración, de describir, conocer y someter a la naturaleza. Esto evidencia una posición en contra a este hecho por parte de los productores del filme, criticándose que no se apliquen derechos a los animales por no razonar. Similar a lo que se aboga en la película 2007: Odisea del espacio, puesto que ésta se basa precisamente en diferenciar a nuestra especie de otras por la capacidad de razonamiento.

De igual forma, se percibe el intento de domesticación de los animales (humanos), costumbre humana que se refleja en lo que hacen los simios con las personas que encuentran, aunque las investigaciones de la doctora reflejan que no existía aun forma de domesticarlos. Se asemeja, por lo tanto, al trato de los humanos con los simios en la vida real, y no a otro tipo de animal. La alusión constante a los ecologistas también es clara en el discurso de la doctora Ziva en defensa de Taylor en el juicio:

-Este hombre tiene derecho a saber cuál es la culpa que se le imputa.

-iMe opongo!. El objeto expuesto es un hombre. No tiene derechos bajo la ley simia. Dra. Zira, es un hombre,

- ¿verdad? - Es diferente a cualquiera que haya visto. $Y$ esperamos poder demostrarlo (El Planeta de los Simios, 1968).

Volviendo a la cuestión religiosa, en la figura
4 se observa la similitud de la vestimenta de los simios con la de los altos cargos de la Iglesia Católica. La casulla y la estola que utilizan en la película son similares a la de los padres católicos. En los sesenta se celebró el Concilio Vaticano II, buscando modificaciones a la religión, es posible que la película se inspirara en estas discusiones religiosas para aprovechar y criticar prácticas de la iglesia como el temory rechazo a la ciencia.

Las críticas a las prácticas de la religión católica continúan a lo largo del desarrollo de toda la película. Cualquier tipo de conocimiento que pusiese en duda la superioridad simia era considerado pecado: "Eso fue antes de que el Dr. Zaius y la Academia dijeran que era una herejía" afirma el simio científico a quien Taylor le cuenta que puede hablar, ante esto el protagonista responde "¿Cómo puede ser herejía la verdad científica?" y continúa la conversación:

¿Cayeron del cielo contigo? (le preguntan a Taylor) "No caímos. Volamos".

Volar es científicamente imposible.

Y aun si no lo fuera, ¿para qué volar?

¿Adónde te llevaría?

"¿Tienen mapas?" (El Planeta de los Simios, 1968)

¿Para qué volar?, se pregunta el Simio, claramente es un cuestionamiento a todo tipo de avance o cambio, para estos religiosos simios todo debe quedarse bajo los mismos parámetros y paradigmas establecidos. Todo lo contrario a lo que buscaban los movimientos sociales de la generación de la contracultura. Generación que abogaba por cambios, nuevos significados, aceptación a quien es diferente, por su etnia, por sus gustos sexuales, $u$ otras razones. Los cambios en materia religiosa se estaban dando con el Concilio Vaticano II precisamente para tratar de mantener

Pensamiento Americano Vol. 12 - No. 23 • 2019 • Enero - Junio • Corporación Universitaria Americana • Barranquilla, Colombia • ISSN: 2027-2448 • 
y conseguir más adeptos de católicos, en un instante en que lo típicamente aceptado y lo conservador era puesto en duda.

Un eslabón perdido entre el primate no desarrollado y el simio.

¡Qué susceptible es!

"No soy un eslabón perdido". Si fuera un eslabón perdido, los textos sagrados no valdrían nada. (El Planeta de los Simios, 1968)

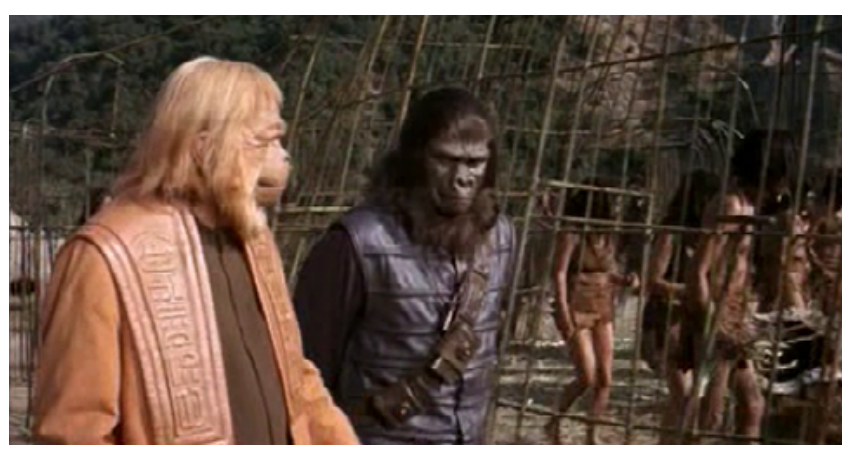

Figura 5. Jaulas de contención de humanos. Fuente: El Planeta de los Simios (1968).

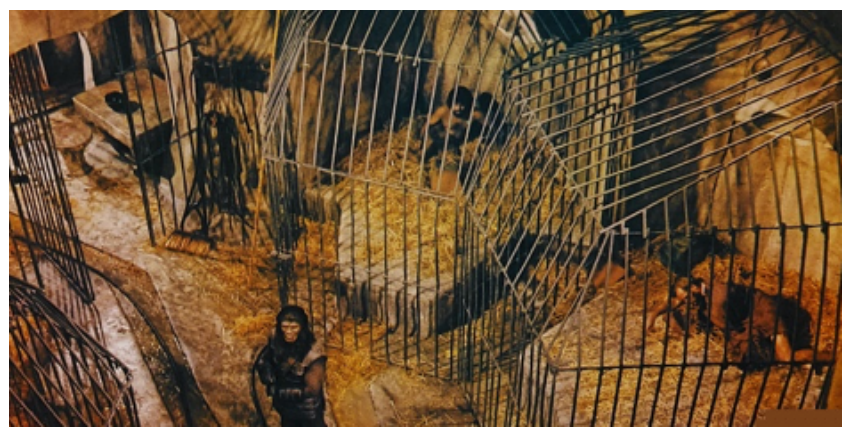

Figura 6. Lugar de investigación con humanos. Fuente: El Planeta de los Simios (1968).

En la figura 5 y 6 es posible observar jaulas en las que se encierran a los humanos, lo cual se asemeja a la forma como se trata a los simios y otros animales en los zoológicos y lugares de investigación que realizan experimentos con distintas especies. En la película los humanos son usados como mascotas y se trata de domesticarlos. De igual forma, la investigación con animales y el hecho de que se hagan experimentos científicos con ellos refleja una forma de crítica negativa a estas prácticas humanas.

En las últimas escenas de la película, el Simio que quiere que se asesina a Taylor lo sigue a él y a la doctora Ziva, ella con dos Simios que la apoyan, a una cueva donde hay vestigios de seres inteligentes antes de los Simios. En este momento el Simio en mención explica que él lo sabe, pero que se debe mantener lo que dice su religión. El hecho de que se oculte información para mantener a las personas alineadas ha sido una realidad de los gobiernos y las iglesias. En el caso de la película, se oculta una fracción de los textos bíblicos simios por conveniencia:

En mi bolsillo. Léale el pergamino 29. Sexto versículo. "Guárdense de la bestia hombre, porque es el instrumento del diablo". "De los primates del Señor es el único que mata por deporte, lujuria o avaricia". "Sí, matará a su hermano para poseer sus tierras. "No le dejéis crecer en número, pues él hará un desierto de su hogar y del vuestro". "Recházale". "Devuélvele a su jungla". "Pues es el precursor de la muerte". - No encontré nada en la cueva que mejorara mi idea del hombre y vivo de acuerdo a ello. La zona prohibida era un paraíso. Su raza lo volvió un desierto hace años. (El Planeta de los Simios, 1968)

Por otro lado, la división de clases también se observa, los orangutanes son la clase intelectual, los chimpancés la dirigente y los gorilas la militar. En esta época eran muy criticados los esquemas tradicionales de clases y estatus quo, los movimientos sociales rechazaban que hubiese diferenciación entre las personas de cualquier forma (Barreira et al (eds), 2013). 


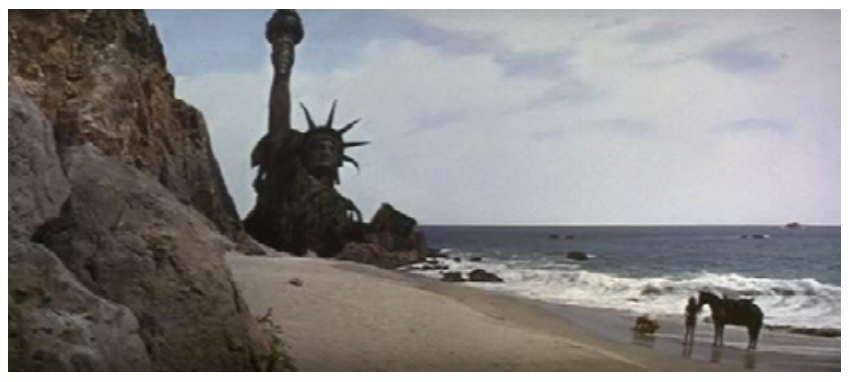

Figura 7. Última escena.

Fuente: El Planeta de los Simios (1968).

Otro aspecto similar a la realidad es la escena final del largometraje (ver figura 7) de destrucción mundial que se asimila al observar una parte de la estatua de la libertad. En la década de los sesenta en el marco de la Guerra Fría había, como se ha mencionado, temor en la sociedad por un posible fin del mundo como consecuencia de guerra atómica, esto pudo haber inspirado ese fin del universo que sucedió en el largometraje.

Al final de la película se entiende que el planeta al que llegaron era la tierra miles de años después, sin embargo, Dodge (uno de los protagonistas que viajaban con Taylor) dijo al tomar una muestra del planeta que no había vida, entonces, ¿cómo es posible que luego encontraran plantas y seres vivos?, tal cual lo explican al final de la película, el ser humano acabó con el planeta. Esto quiere decir que la zona que Dodge definió como no apta para tener vida puede que haya sido resultado de la perspectiva de la época del peligro de las armas químicas como las bombas atómicas, así que es posible que el hecho de que una parte del planeta estuviese inhabitable, sea porque finalmente el ser humano destruyó al planeta con su uso irracional de los recursos o por armas químicas. En esta década es muy fuerte el movimiento ecológico y de reivindicación de la naturaleza, así que estos hechos son una crítica a lo que podría suceder si el ser humano continúa tratando al planeta como lo hace, o continúa una guerra atómica.
¿Cómo pudieron llegar al planeta tierra miles de años después y seguir con vida?, los personajes explican que ellos han envejecido solo 18 meses por haber estado en hibernación, mientras el tiempo transcurrido realmente es de 2006 años, previendo entonces que están en el planeta tierra en el año 3978 ya que salieron en el año 1972. Vale recordar que Taylor, que es el único que sobrevive de los astronautas después de que son cazados por los simios en un maizal, solo se entera de esto en la última escena. En los sesenta se retoma, después de 1915, la teoría de la relatividad de Einstein. El historiador Alexander Blum afirma que "en los años 60 y 70 la teoría de la relatividad general volvió a un primer plano" (Blum, Lalli \& Renn, 2015, p. 2). La explicación fue entre otras cosas "el descubrimiento de cuerpos celestes exóticos, muy distantes, cuyas características particulares se podían explicar con la teoría de Einstein. Por ejemplo, los agujeros negros y el hecho de que su enorme campo gravitacional no reflejara la luz" (La Jornada, 25 de noviembre de 2015). La interpretación de cómo los astronautas sobrevivieron al paso del tiempo y lograron volver a la tierra miles de años después es una forma de destacar esta teoría de la relatividad, que es precisamente la que permite comprender esta posibilidad. El protagonista afirma que viajaron a la velocidad de la luz, lo cual también es extraído de la teoría sobre la velocidad uniforme de la luz de Einstein. Aunque en la película se hable de un doctor Otto Hasslein a.k.a. Albert Einstein.

En las imágenes de la película 2001: Una Odisea del Espacio también se observan aspectos de crítica relacionados con el contexto. Y ambas películas, estrenadas en 1968, tuvieron gran acogida en el público, en el marco de la Revolución de 1968. Incluso un gran festival de cine, el de Cannes, es interrumpido debido a las revueltas estudiantiles de mayo de forma súbita (Delahaye, 2008). Ambas películas son de ciencia ficción, y especialmente 2007: 
Una Odisea del Espacio ha sido considerada en esta década como la obra cinematográfica de ciencia-ficción más exitosa, en especial por tocar el tema del futuro de la vida del humano y su "eterno sueño por conquistar el espacio. Incluso resultó ganadora del Oscar de la Academia en la categoría de mejores efectos visuales y es nominada en las categorías de mejor director, mejor guion cinematográfico, y dirección artística" (Filmaffinity, s.f).

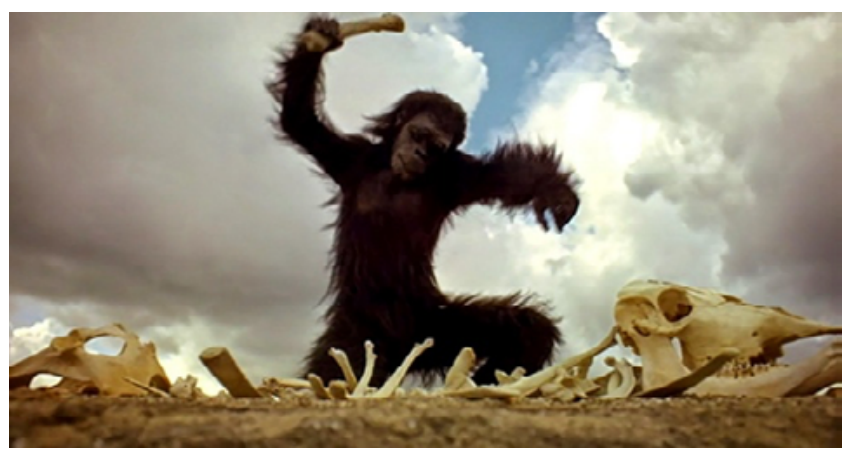

Figura 8. Primeras escenas.

Fuente: 2001: A Space Odyssey

La trama de 2001 gira en torno al tema de la inteligencia. La experiencia audiovisual que ofrece la película no pretende más que motivar al espectador a reevaluar su contexto, abordando diálogos simples, pero conclusiones muy claras como que la inteligencia y la inventiva, la recursividad de utilizar las herramientas que se presentan ante el ser o las creadas por el mismo, son la esencia básica de la naturaleza humana. En la película humanidad es igual a inteligencia, ingenio e inventiva. Las constantes referencias a las capacidades de la humanidad con la computadora Hall 9000 y yuxtapuestas son reflejo de las imperfecciones de esta, reflejando los vicios de la naturaleza humana que hacen notar que no debe tomarse la condición humana con indulgencia.

Kubrick logra desligar al personaje cinematográfico de ese contexto para alcanzar un enfoque casi documental de lo que fue antes y lo que logrará la humanidad, desde que los antepasados empuñan la primera herramienta (figura 8), hasta que conquistan finalmente el universo a los ojos de finales de los sesenta. La película desarrolla tres momentos importantes. El primero se da en el génesis de la humanidad y la confrontación del poder de asombro y el rechazo a lo que nos es extraño. La segunda parte con la conquista misma del universo y la exploración de lo desconocido. Finalmente, la búsqueda de vida inteligente, en una entramada serie de eventos desafortunados producto de la curiosidad e inventiva humana.

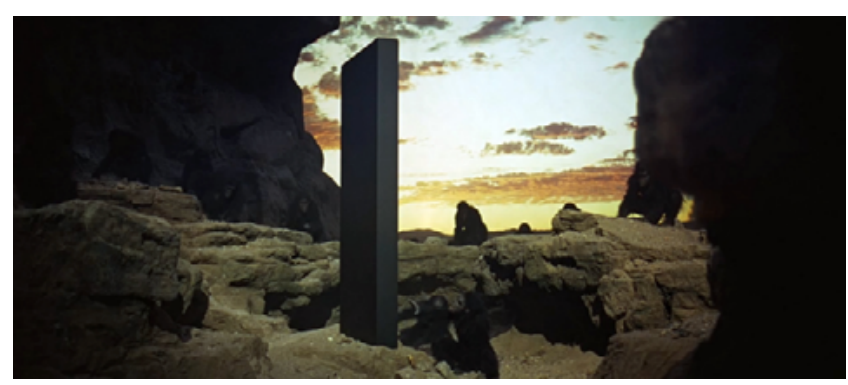

Figura 9. Escenas iniciales de la película. Fuente: 2001: A Space Odyssey

La figura 9 muestra la primera parte de la película, en la que se nota como los simios sobreexcitados por la presencia del monolito se exaltan ante la figura que les es ajena a todo paisaje conocido para ellos hasta entonces. Siempre que aparece un monolito en la película se da un salto a otra parte de la misma, así pues, el monolito hace una alegoría a las transformaciones sociales que sufrió la humanidad a lo largo de la historia, sea la crisis de los misiles en Cuba en el 62, el Mayo del 68 en Paris o un hombre negro gritando "i have a dream" en la lucha por los derechos para los afroamericanos; el monolito representa a lo largo de la película las transformaciones en momentos coyunturales que generaron en el ser humano un cambio, superar lo primitivo, abordar lo futurista para volver real lo que antes era mítico. Si bien en la película 2007: Una Odisea del Espacio se evidencian tres monolitos, este les representa una gran importancia a las 
caracterizaciones del ser humano moderno y del personaje cinematográfico pues en la fase más tosca de la inteligencia humana, así como en la más fina, el rechazo a lo desconocido, lo diferente, lo inexplorado, suele superar al principio la curiosidad que operativiza la inteligencia.

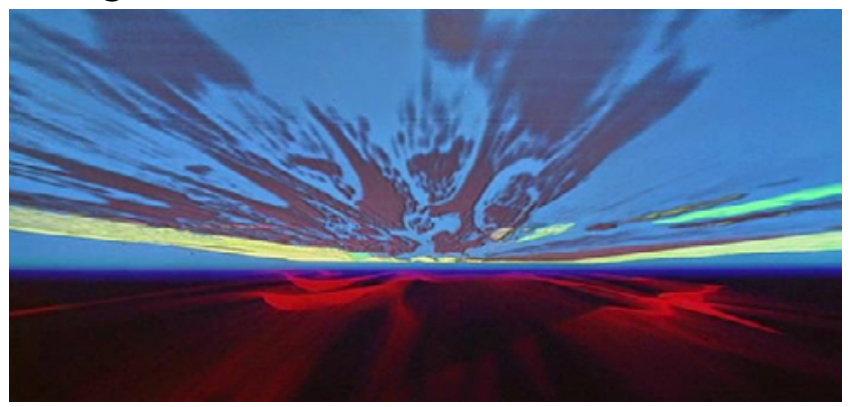

Figura 10. Escena del viaje.

Fuente: 2001: A Space Odyssey

El viaje psicodélico que experimenta el Dr. Floyd al final de la película (figura 10) es una clara referencia a todos los movimientos de contracultura y antisistema de la época, cuando muchos Hippies rechazaban la religión y la búsqueda individual de la espiritualidad primaba. La Figura 10 muestra como Floyd protagoniza la experiencia audiovisual y sensitiva culminando con el encuentro entre el humano y su aparente creador. La década de los sesenta vio crecer la generación que experimentó con psicotrópicos luego de ver el LSD salir de los laboratorios al final de la década. El final de 2007: Una Odisea del Espacio muestra una representación de la búsqueda de experiencias alucinógenas, y puede que el director buscara generar en las personas que observaran la película la sensación similar a un viaje intergaláctico a la manera de las sensaciones de sentirse drogado.

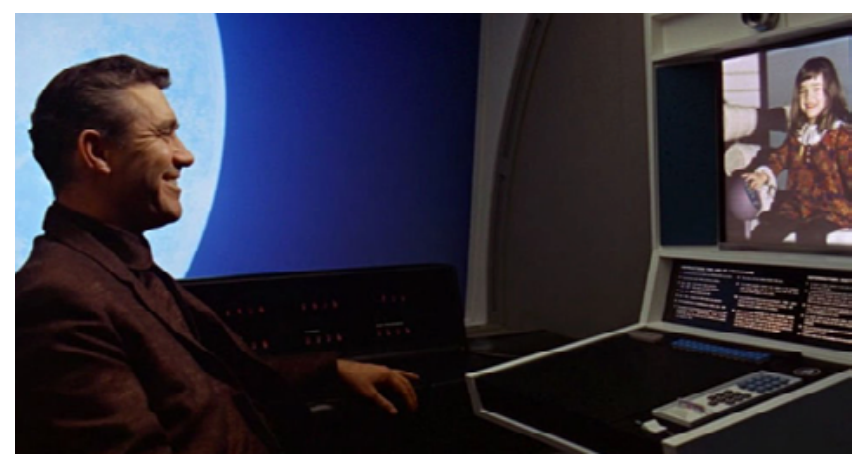

Figura 17. Escena de comunicación de la estación espacial con la tierra.

Fuente: 2001: A Space Odyssey

En 2001 es posible identificar a partir del discurso la normalización de los viajes al espacio, la perspectiva de que se podrán hacer con total tranquilidad y normalidad, prácticamente al nivel de un aeropuerto. Las instalaciones y las alusiones constantes a la estructura de la estación espacial y la tecnología de comunicaciones con la tierra son indicadores de esto. En una conversación normal entre el protagonista y un colega se evidencia esto:

Lleva 7 ó 8 meses sin estar aquí, ¿verdad? A ver. Sí, unos ocho meses. ¿Supongo que vio las obras de la nueva sección? - Van muy bien, ¿no?

- Sí, van bien.

¡Un momento! Tengo que hacer un par de llamadas. Nos vemos en el restaurante. (2007: Una Odisea del Espacio, 1968)

Los avances tecnológicos expresados en la película son claros, incluso en una video llamada (forma de comunicación que no era común en esa época de los 60 's) la hija del personaje de la película le afirma que ya tiene demasiados teléfonos:

¿Quieres algo especial?

- Sí.

¿Qué? <i> Un teléfono.</i>

Ya tenemos muchos teléfonos. (2001: Una Odisea del Espacio, 1968) 
Ya en la década del treinta se había desarrollado el "PicturePhone", pero fue hasta los sesenta que el público tuvo acceso a esta tecnología que fracasó por su alto costo, sin embargo, en 2007: Una Odisea del Espacio, el Dr. Floyd pagaba apenas 1.7 dólares por comunicarse en una videoconferencia con su hija.

De igual forma, es posible observar del discurso y las imágenes que la estación es de Estados Unidos y que todo en dicho espacio va avanzando y mejorando. Incluso hay algunas señales de la empresa Hilton y de la aeronáutica estadounidense. $Y$ en el marco de la Guerra Fría la estación estadounidense iba viento en popa. Una doctora con la que conversa en medio de un grupo que toma café en la sala de espera del espacio le afirma al protagonista recién llegado que:

Pasamos los últimos 3 meses calibrando la nueva antena en Tchalinko.

- ¿Y tú?

- Yo estoy de camino a Clavius.

¿Ah, sí?

Dr. Floyd, no quiero parecer demasiado curioso... ...pero quizá Ud. pueda clarificar el misterio sobre lo que ocurre allí. (2007: Una Odisea del Espacio, 1968)

También se identifica una versión de que en el futuro incluso habrá leyes sobre los viajes al espacio y acuerdos internacionales al respecto:

Y hace 2 días, no dieron permiso a un autobús espacial...para un aterrizaje de emergencia.

Sí, es raro.

Creo que eso va a crear problemas. Negar el permiso para aterrizar viola la Convención de IAS. (2001: Una Odisea del Espacio, 1968)

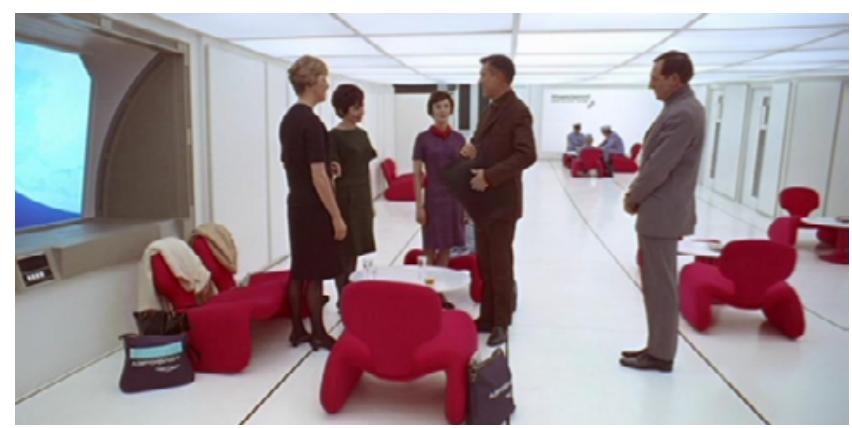

Figura 12. Sala de espera de la estación espacial. Fuente: 2001: A Space Odyssey

La Figura 12 muestra a un grupo de científicos sostener una breve y fortuita reunión en la que se comenta un problema con las comunicaciones con la luna, la negación a un permiso de aterrizaje y una posible epidemia que puede ser la razón de estos incidentes, sin embargo, el Dr. Floyd (personaje que tiene conocimiento de estos sucesos) evita discutir al respecto. El que las operaciones de exploración y explotación estuvieran en cabeza de científicos principalmente, podía considerarse una crítica a la característica fundamental del viaje espacial: los tripulantes suelen ser militares de carrera. Si bien la pericia científica de Frank Borman (Comandante del Apolo 8) le significó una Medalla del Congreso sobre Tecnología Espacial (máxima condecoración militar en los Estados Unidos de América), esto no hubiera sido posible de no ser por su carrera militar. Esta representa una clara crítica a la hegemonía militar en la carrera espacial, misma que desplazaba en la época a un segundo plano la relevancia científica que a fin de cuentas pone al ser humano en el espacio.

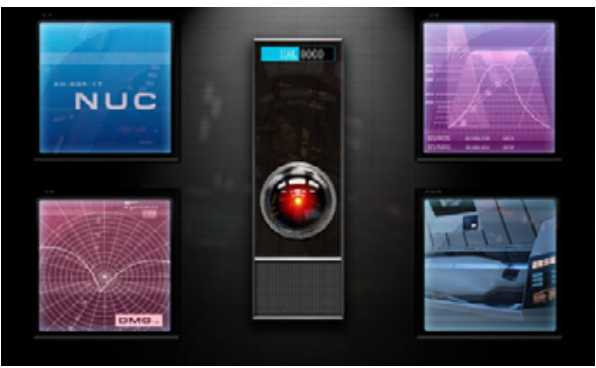

Figura 13. Consola de comunicación con la computadora Hall 9000.

Fuente: 2001: A Space Odyssey 
La tercera parte de la película se desarrolla principalmente en una nave espacial americana llamada "Discovery 1" con rumbo a Júpiter, siendo el primer intento por alcanzar tan distante planeta. Esta nave cuenta con una tripulación de 5 hombres y una computadora con inteligencia artificial, Hall 9000 la cual se observa en la figura 12. Esta computadora está a cargo de las funciones principales de navegación y de mantener constante vigilancia a 2 de los 5 tripulantes que se encuentran en hibernación. Tal ficción es solo una muestra de lo que ya venía y quería seguir logrando la humanidad a finales de los sesenta con el desarrollo de los circuitos integrados para las memorias RAM que hoy día se ocupan de todas las ordenes que ejecuta el procesador de nuestras computadoras y en ese entonces impulsó el desarrollo tecnológico computacional. En esta década también orbita por vez primera un satélite de comunicaciones de EEUU.

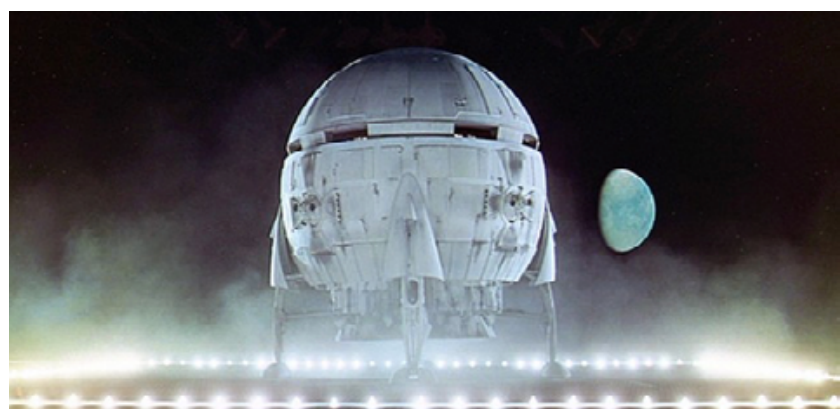

Figura 14. Imágenes del alunizaje.

Fuente: 2001: A Space Odyssey

Uno de los problemas principales en la carrera espacial, y especialmente por poner un hombre en la luna, era la cuestión del "alunizaje", el cual se resolvió con el módulo lunar que permitiría poner a la humanidad por vez primera en la luna y retornar satisfactoriamente a la tierra. La Figura 13 muestra la versión de un alunizaje futurista, con un módulo lunar estilizado y que, más allá de su forma esférica, guarda mucha relación con el empleado por la tripulación del Apolo 8, vislumbrando la travesía que tendría lugar en 1969.

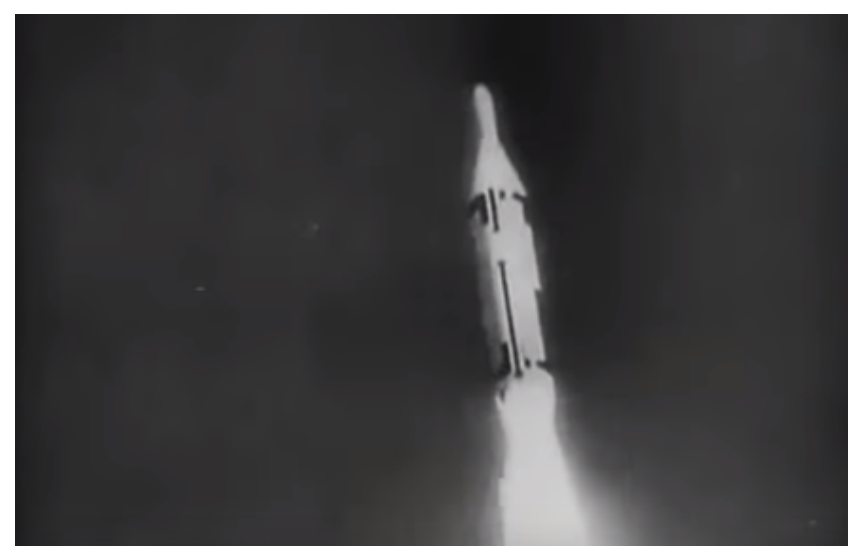

Figura 15. Despegue de la nave Prometeus. Fuente: Solaris (1968).

Pasando ahora al análisis de la tercera película, Solaris, es menester destacar que empieza con unas imágenes que corresponden al despegue de la nave Prometeus que viaja hacia Solaris (Figura 15). Se observa al inicio una serie de equipos que incluso parecen sintetizadores, pero que realmente hacen referencia a la tecnología de la estación espacial y de la nave.

En las primeras imágenes se desarrolla un discurso de conversación entre el capitán y la computadora central de la estación, vale agregar que él es un psicólogo, que fue encomendado a última hora a esta misión, lo que evidencia que cualquier persona podría viajar gracias a la automatización tecnológica. Aparte de esto, hay una forma de decirle a la gente que, en un futuro muy cercano, se va a hacer tal uso de las computadoras, que se va a alcanzar tal nivel de desarrollo, que son las maquinas las que van a controlar todas las operaciones y el ser humano simplemente se va a encargar de pensar y lograr ciertas acciones, pero aquellas relacionadas con aterrizaje, manejo de reactores, etc, son totalmente controladas por las computadoras. 


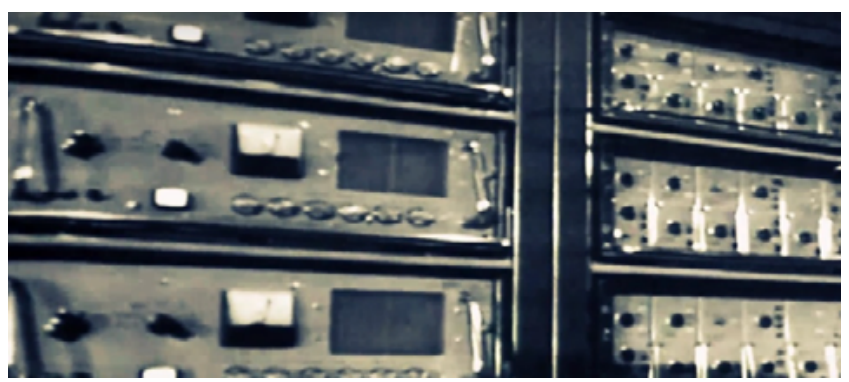

Figura 16. Consola o tablero de control de la nave. Fuente: Solaris (1968).

La cantidad de botones y equipos están de alguna forma probando la complejidad de un desarrollo científico en el área de los viajes espaciales. En vez de una única palanca o un botón, son muchos, como una manera de decir que se necesita un gran tablero y una gran cantidad de elementos para realizar los viajes por fuera de la tierra. En plena carrera espacial, es una forma de hablar de complejidad, incluso se habla de orbitar planetas y tener estaciones espaciales permanentes lejos de la tierra. En una época en que el ser humano ni siquiera ha llegado a la Luna, ya en la película se considera que este ha logrado la exploración interplanetaria. Esta asunción aplica también para las películas previamente analizadas. En este caso, la perspectiva es desde Rusia, notándose que es este país el que logra un gran desarrollo tecnológico y gana la carrera espacial. Se percibe que es la Unión Soviética, la que, según el filme, logra aventurarse y explorar otros planetas.

Vale recordar que la época en la que se estrena el largometraje es el momento de la Guerra Fría, la misma que con sus inicios dio lugar a que nacieran los satélites en el año 1946, en el marco de la carrera espacial (Tirado, 2014). Al principio del filme se menciona: "La nave "Prometeus" desacelerando en dirección a Alfa Acuario. Para lanzar un transporte a la estación científica en la órbita del planeta Solaris" (Solaris, 1968). En ese sentido, el hecho de que la nave se llame Prometeo, puede que sea una alusión al dios que busca traer conocimiento y luz.

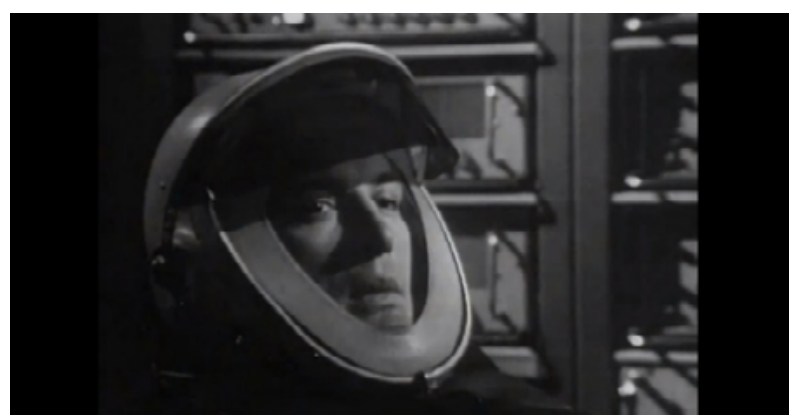

Figura 17. Imágenes del protagonista. Fuente: Solaris (1968).

Se supone que la película es para público soviético, es pensada probablemente para demostrar a partir de la ciencia ficción que la URSS está cerca de lograr avanzar mucho más rápido y cumplir grandes objetivos relacionados con los viajes por fuera de los límites del planeta tierra. Cuando el cosmonauta llega a la estación, se nota que los que ahí estaban llevaban años en ahí. Es una estación perfectamente acondicionada para que los humanos puedan sobrevivir por grandes periodos temporales en el espacio.

Los trajes de los cosmonautas difieren de los que se observan en las dos películas norteamericanas (figura 17) y se enfatiza mucho en el hecho de que sean científicos, incluso Kelvin es psicólogoy va a evaluar la situación. Esto sucede gracias al avance que se demuestra en la película con respecto a la tecnología y la computación. Como se mencionaba, cualquier persona puede viajar porque todo está automatizado y lo realiza la computadora.

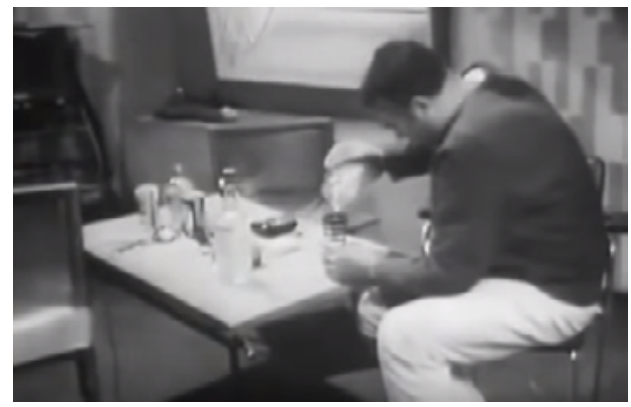

Figura 18. Imágenes del pasajero que ya estaba en la estación espacial.

Fuente: Solaris (1968). 
Una de las primeras imágenes que se observan de unas personas distintas al personaje principal, es un hombre bebiendo vodka y fumando tabaco, algo muy de la idiosincrasia soviética. Este es un cuadro con el que se relaciona mucho a los rusos, la gente bebe como algo común de su costumbre, incluso en momentos de crisis económica se obsequiaba vodka (Ponce, 2011). El tema de fumar, como algo común, era permitido en lugares cerrados y de estilo, es evidencia de una época en que aún no se han reforzado leyes prohibicionistas para los fumadores. El licor está muy asociado también con la idiosincrasia soviética.

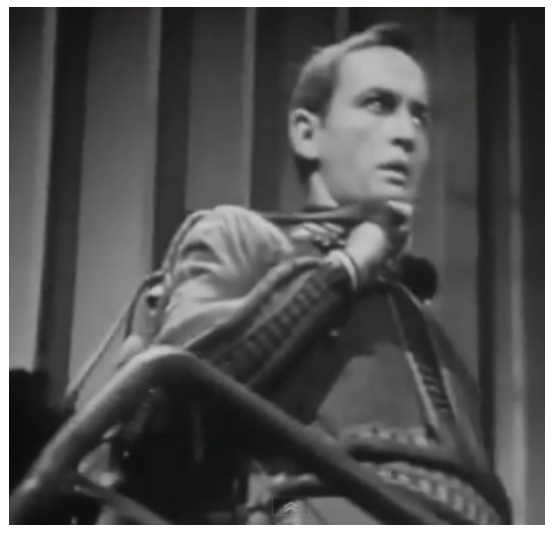

Figura 19. Protagonista de la película.

Fuente: Solaris (1968).

El cosmonauta que llega a la estación Prometheus es Kelvin (figura 19), quien es un psicólogo que va a averiguar si ocurren cosas extrañas a las personas que viven y hacen investigaciones en la estación espacial frente al planeta Solaris. Al principio afirma "En aquel entonces me parecía que iba a un mundo que conocía y al que estaba acostumbrado" (Solaris, 1968). En general la película refleja que la carrera espacial lleva a los humanos a tener la capacidad de comunicarse con vida inteligente extraterrestre. A diferencia de 2001, Solaris no es una película de ciencia ficción con grandes escenarios y desarrollo cinematográfico. Contrario a esto, se centra más en desplegar un discurso moral y filosófico complejo con respecto a la vida y la relación del ser humano con Dios. Esto se distingue mucho en el desarrollo discursivo del encuentro con Kelvin y el "visitante" (ser creado por la vida inteligente de Solaris que es reflejo de los sentimientos de una persona) que recrea la existencia de su esposa, quien en la tierra se habría suicidado 10 años atrás (figura 20). Contrario a lo que suele pensarse, la película recrea un escenario alternativo de vida extraterrestre. No se concibe la existencia de un ser extraterrestre extraño, sino un ser igual al humano, que busca de alguna forma conocer y extraer información de los cosmonautas.

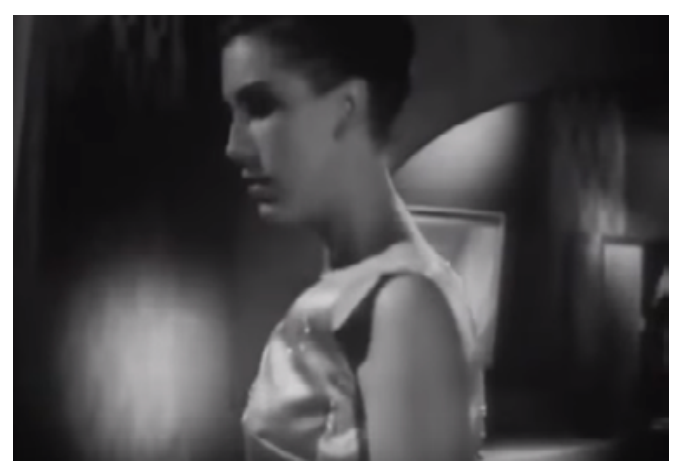

Figura 20. Visitante extraterrestre que simula ser la esposa del protagonista.

Fuente: Solaris (1968).

Todo lo relacionado con el romance entre el protagonista y el ser del espacio que es idéntico a su esposa (figura 20), y que mantiene todos los recuerdos y personalidad que guarda sobre la misma el protagonista, refleja que se concibe lo que los viajes al espacio van lograr en la esencia del ser humano, más allá de la luna, hasta el punto de orbitar un planeta y tener una estación permanente frente a un planeta, como algo que implicará más que avances tecnológicos situaciones de entendimiento del ser, de la comprensión de sí mismos de quienes viajen al espacio, que se podrán encontrar con debates existenciales. No solo se interpreta como el viaje por la tecnología sino como una búsqueda de experiencias. 
La película se enmarca en una reflexión ante lo que es la vida y el significado real de lo que sucedería si el ser humano explora lugares distintos a la tierra y se encuentra no solo con seres extraterrestres, sino también con seres que hacen que el ser humano indague sobre sí mismo.

El drama de los seres humanos expuesto por un director ruso es reflexionado en esta película. Una percepción de los viajes al espacio arraigado más a un romance que a una lucha con Estados Unidos. Menos importancia a lo tecnológico y a los efectos, y más importancia al dialogo y a las vivencias. Distinto a lo que sucede con 2001, que se basa más en imágenes y menos en diálogo.

Al igual que en 2001, con la computadora HAL, y que, en El Planeta de los Simios, con los simios, los "visitantes" son muy parecidos a los humanos, poseen inteligencia y sentimientos, poniéndose en duda que es realmente la razón lo que distingue a la especie humana de cualquier otro ser que exista o podría existir. Debates existencialistas en una época de transformaciones y dudas sobre el auto reconocimiento de los jóvenes de una generación que tenía todo y sin embargo se sentían que nada le pertenecía. En Solaris no es el ser humano analizando, sino siendo analizado y controlado por otra especie. Esta película, al igual que las otras dos, son reflexiones desde afuera, observando al humano desde lejos para saber cómo actúa en el futuro, cómo actúa cuando se encuentra con situaciones resultado de sus avances científicos, sean buenas o malas.

Al final en una conversación entre Kelvin y Snout y luego en un monólogo del primero en mención se afirma: "-Ella vendrá de nuevo. - No lo hará. - Ella volverá. Enviamos tus mensajes al océano ayer, no ha habido visitantes desde entonces". (Solaris, 1968)
Y yo ¿qué es lo que quería? ¿regresar a la tierra? ¿para qué? ¿no tengo casa ni familia? Sin embargo, decidí volver. Todos volvemos a la Tierra desde las estrellas. ¿O debo quedarme aquí con Snout? No sabemos si el océano abandonara la idea del contacto con los humanos. Tenía sus propias metas ¿Tendrá éxito o no? ¿Va a repetir el experimento? No, no puedo volar y dejarla atrás. ¡Me quedaré en Solaris! ¿para qué? ¿Espero que Harrie vuelva? No hay tal esperanza nunca más. Pero estoy esperando. ¿Qué piensa una mente ajena a la nuestra? No tengo ni idea. Pero la única cosa que sé es. Hay milagros crueles cuando suceden. (Solaris, 1968)

En el diálogo de Solaris se hace continua alusión a la importancia de encontrar vida en otro planeta, y que al conseguirla se halla es a unos visitantes que los analizan y los quieren conocer a ellos. La falta de control sobre la situación y la autosugestión consecutiva sobre los sentimientos del protagonista con respecto al "visitante extraterrestre", que es igual a su esposa muerta hace una década, son constantes.

\section{Conclusiones}

El cine ayuda al estudio de la historia desde una ventana que admite vislumbrar caracterizaciones y representaciones de inquietudes, temores, avances, encuentros, tensiones o temores que otros recursos no alcanzan, al menos, con el impacto audiovisual que el cine logra concretar. Por tal razón, este trabajo se centró en el análisis de tres obras cinematográficas como una herramienta para el estudio de la historia, entendiendo que las expresiones críticas del cine constituyen representaciones de un contexto que permiten el análisis de la historia a través de este medio audiovisual. Este trabajo se concentró en 
realizar un análisis del discurso y la imagen de 2001: Una Odisea del Espacio, El Planeta de los Simios y Solaris, tres películas de finales de la década de los sesenta sobre los viajes espaciales que llegaron al público en un contexto en el que los movimientos juveniles de contracultura, las transformaciones conceptuales respecto de las experiencias sexuales, espirituales, la conexión con la naturaleza, el futuro de la humanidad, la guerra y los debates existenciales entre religión y ciencia, estaban presentes con especial fuerza en occidente.

En el estudio realizado se logra identificar en el cine una institución social como lo mencionaba Manuel Romero Trenzado (1999), y equiparar a las películas como discursos comunicativos concretos, puesto que reflejan una serie de exposiciones dialógicas acordes al contexto del momento, con tendencias críticas de los argumentos, lo cual se percibe en los diálogos de reflexión en los que se alude a adjetivos calificativos y a reacciones de los protagonistas. El mejor ejemplo es el momento en el que el protagonista de la película El Planeta de los Simios se da cuenta que el lugar en el que se encuentra es la tierra, y que todo ese tiempo ha estado en Nueva York. El elemento representativo de la Estatua de la Libertad, sus frases de "al fin lo hicimos destruimos el mundo" y su reacción de conmoción ante lo observado, son claramente una crítica a la humanidad y una reflexión ante lo que puede ocurrir si se sigue el camino de destrucción que el protagonista percibió antes de salir del planeta.

Los discursos que evidencian los filmes son ejemplos claros de las críticas e inquietudes sociales que alrededor de 1968 recurrían. Si bien aspectos alejados de la realidad, como lo afirmaba Marc Ferro (1995), como las exageraciones u otros aspectos utópicos, son claros y notables en las películas analizadas por el simple hecho de que pertenecen a la categoría de cine de ciencia ficción y no de cine histórico, estos no desligan la alegoría que hacen de las realidades representadas en las mismas y las críticas que se hacen al contexto de los años sesenta. Por ejemplo, el temor a lo que podría suceder si seguía avanzando la tecnología, el rechazo a ciertas tradiciones religiosas, las preocupaciones por la relación hombre-naturaleza (En El Planeta de los Simios), la naturaleza de cambio del ser humano, y la similitud al que pueden llegar a tener las computadoras (en 2001), los debates sobre el ser, el amor y la existencia misma (en Solaris), y otros tantos temas que, sin duda alguna, se encontraban en la mente de los realizadores.

En el cine se representa las aspiraciones mismas del ser humano en sociedad o solitario e incluye indicios o preocupaciones sobre el potencial, aunque a veces ficticio, de la humanidad dadas las coyunturas del momento. De allí que "los contextos no permanecen uno junto al otro sin hacerse caso mutuamente, sino que se encuentran en un permanente estado de intensa e ininterrumpida interacción y lucha" (Voloshinov, 1993: 114). Asimismo, las películas analizadas, reflejan las utilidades que puede tener el cine como fuente para la historia. Es una evidencia de una época específica en que los viajes al espacio y las críticas sobre las posibles consecuencias por el desarrollo tecnológico del hombre, así como a los excesos y abusos del ser humano sobre la naturaleza, están presentes.

Por otro lado, al buscar si hay ideas de reflexión, contestatarias o críticas respecto a algún elemento de la época, que es lo que sucede cuando las películas, como discursos comunicativos concretos, expresan posiciones en contra o a favor del espíritu de la época, se podría afirmar que los tres filmes apoyan claramente que su bloque, Estados Unidos, o la Unión Soviética, sea el que prepondere en 
la carrera espacial y la Guerra Fría, pero que los resultados de estos avances pueden dar lugar al entendimiento de aspectos que podrían poner en juego la continuidad de la vida en la tierra como se conoce. Las tres obras además permiten verificar ¿qué es lo que nos distingue y nos hace humanos?, si la respuesta es la razón y los sentimientos, los simios, la computadora, los monos, y los visitantes de las películas, son humanos, si a esto se le agrega la capacidad de comunicarse, todos los mencionados son humanos. Lo que hace humanos a esta especie, puede que sea difuso, y lo que sucedería si se continúa en el camino del desarrollo tecnológico, aspecto típico de la década de los sesenta, es llegar a consecuencias como la destrucción del entorno. Este tipo de películas invitan a la reflexión sobre la posición de la humanidad como desestabilizadora, interventora, destructora, o dominante de la naturaleza, creencias que el cine ha ayudado a consolidar en el imaginario social, en especial cuando a la conquista del espacio y a la tecnología se refiere.

\section{Referencias}

Agel, J., \& Agel, J. (Eds.). (1970). The making of Kubrick's 2001 (pp. 328-354). New York, NY: New American Library.

Barreira, C., González, R. \& Trejos, L. F. (eds.). (2013). Violencia política y conflicto sociales en América Latina. Barranquilla, Colombia: Universidad del Norte y CLACso.

Blum, A., Lalli, R., \& Renn, J. (2015). The reinvention of general relativity: A historiographical framework for assessing one hundred years of curved space-time. Isis, 706(3), 598-620.

Boulle, P. (1963). La planète des singes (The planet of the apes). Paris: French \& European Pubns.

Burckhardt, J. (2004). La cultura del Renacimiento en Italia (Vol. 106). Ediciones AKAL.

Burke, P. (2005). Visto y no visto: el uso de la imagen como documento histórico. Barcelona: España, Crítica.

Burckhardt, J. (1869). Cultur der Renaissance in Italien ein Versuch von Jacob Burckhardt. Roma: EA Seemann.

Caparrós, L. J. M. (1997). 100 películas sobre Historia Contemporánea. Madrid, España: Alianza Editorial.

Clarke, A. (1951). Sentinel of Eternity. 10 Historias de Fantasía. The Avon Science Fiction and Fantasy Reader publicado por Avon Periodicals, Inc.

Delahaye, M. (2008). Cannes-1968: fin de un festival. Cahiers du cinema España, (12), 78-80.

De Meneses, U. T. B. (2002). A fotografia como documento-Robert Capa e o miliciano abatido na Espanha: sugestões para um estudo histórico. Tempo, (14), 131-151.

Díaz, J. J. (s.f.). Historia Contemporánea y Cine: La imagen fílmica como herramienta histórica y recurso didáctico. Granada: Universidad de Granada. Recuperado de: http://mww.ugr.es/ histocon/html/historiacontemporaneaycine.html

Edwards, E. (2012). The Camera as Historian: Amateur Photographers and Historical Imagination, 18851918. Duke University Press.

Ferro, M. (1995). Historia contemporánea y cine. España: Ariel. 
Ferro, M. (2008). El cine, una visión de la historia. Madrid, España: Ediciones AKAL.

Filmaffinity. (s.f). 41 Edición de los Oscar (1969) - Películas de 1968. Recuperado de: https://mww.filmaffinity. com/co/awards.php?award_id=academy_awards\&year=1969

Gaviria, R. O. (2012). El discurso evolutivo de Nietzsche en la odisea espacial de Kubrick. Bogotá, Colombia: Master's thesis, Universidad EAFIT.

Gisbert, M. V. (2012). La intertextualidad fílmica en la audio descripción (AD). Intralinea on line translation journal, 14.

Hegel, G. W. F. (2017). Fenomenología del espíritu [versión original de 1807 en alemán]. México: Fondo de cultura económica.

Huizinga, J. (2001). El otoño de la Edad Media: estudios sobre la forma de la vida y del espíritu durante los siglos XIV y XV en Francia y en los Países Bajos. Alianza Editorial.

Kurlansky, M., \& Antón, P. (2005). 1968, el año que conmocionó al mundo. Barcelona: Destino.

La Jornada. (25 de noviembre de 2015). Cumple 100 años la revolución de la teoría de la relatividad. Recuperado de: http://mww.jornada.unam.mx/ultimas/2015/11/24/ cumple-100-anos-revolucion-de-la-teoria-de-la-relatividad-4644.html

Laurent, V. (2009). Mayo del 68, cuarenta años después. Entre herencias y controversias. Revista de estudios sociales, (33), 29-43.

Lázaro, J., Salcedo, L., Guerra, A., Jimenez, M., DAmato, G., Maldonado, C., Corena, E. (2017). 1968. Entre las tensiones del mundo bipolary las esperanzas de que todo puede ser posible. Barranquilla: Sello editorial Coruniamericana.

Lem, S. (1961). Solaris, trans. Joanna Kilmartin and Steve Cox. Solaris, The Chain of Chance, A Perfect Vacuum (London: Penguin, 1981), 32.

MacGregor, D. (2009). 2001; or, How one film-reviews with a hammer. Visual-Memory. Retrieved September, 29.

Montero, J. \& Paz, M. A. (1997). La historia que el cine nos cuenta: el mundo de la posguerra 1945-1995. Madrid,
España: Tempo.

Paz, M. A. \& Montero, J. (1995). Historia y cine: realidad, ficción y propaganda. Madrid, España: Complutense.

Ponce, L. E. (2011). Papa chilena, el vodka y su influencia en la Segunda Guerra Mundial: frente ruso. Idesia (Arica), 29(3), 117-124.

Rábago, D. M. (2013). Interculturalidad, universidad y movimientos sociales latinoamericanos: ideas desde la frontera norte. Sociedade e Cultura, 16(2).

Renier, G. J. (2016). History: its purpose and method (Vol. 34). Routledge.

Romero, M. T. (1999). Cultura de masas y cambio político: El cine español de la transición. Madrid: CIS.

Rubio, M. H. \& Rubio, M. A. (2006). Breves comentarios sobre la historia del tabaco y el tabaquismo. Revista del Instituto Nacional de Enfermedades Respiratorias, 19(4), 297-300.

Schaffner, F.J. (1968). El Planeta de los Simios [DVD-Vídeo] $=$ (Planet of the apes). Estados Unidos: APJAC Productions. 20th Century Fox.

Tal, T. (2005). Alegorías de memoria y olvido en películas de iniciación: Machuca y Kamchatka. Aisthesis: Revista chilena de investigaciones estéticas, 38, 136-51.

Tirado, M. Á. (2014). Los años 60: una revolución en la cultura. Bogotá, Colombia: Debate.

The Michigan Daily. (4 de junio de 1968). Parte superior de la portada de la revista. Michigan: Ann Arbor.

Voloshinov, V. (1993). El marxismo y la filosofía del lenguaje. Madrid, España: Alianza.

Wheat, L. F. (2000). Kubrick's 2001: A triple allegory. Boston: Scarecrow Press.

Zepke, S. (2007). Against Nihilism, Nietzsche and Kubrick on the Future of Man'in. Journal of French Philosophy: Bulletin de la Société Américaine de Philosophie de Langue Française, 17(2).

2018, Vol. 12(23) 200-224 @The Author(s) 2018 Reprints and permission: www.americana.edu.co

https://www.coruniamericana.edu.co/publicaciones/ojs/index.php/pensamientoamericano/index 